\title{
Haosul hazardului sau cosmosul determinismului?
}

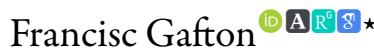 \\ Facultatea de Litere, Universitatea „Alexandru Ioan Cuza”, Bd. Carol I 11, 700506 Iași, România
}

\section{Despre articol \\ Istoric:}

Primit 13 iulie 2020

Acceptat 8 august 2020

Publicat 27 decembrie 2020

Cuvinte-cheie:

teleologie

determinism

neodarwinism

aleator

\begin{abstract}
Rezumat
Tot ceea ce există decurge din ceva anterior și se supune unor factori determinanți, adică are antecedenți și cauze, care dețin antecedenți și cauze, indiferent de dificultatea de a analiza exhaustiv elementele lanțului cauzal (adică de a le cuantifica forțele, ierarhia, și ponderile, de a le stabili gradele de conjuncție, interdeterminare și colaborare, de a le monitoriza, matematiza și algoritmiza componentele), nimic nefiind aleatoriu și lipsit de determinare. $\mathrm{O}$ astfel de dificultate sau de imposibilitate nu poate genera sau constitui motiv de a concluziona că astfel de procese complexe ar fi indeterminate și aleatorii, întrucît ele sînt riguros determinate de o multitudine de factori inextricabil întrețesuți.
\end{abstract}

"The influence of an ideology depends upon the meaning it maintains in the minds of its adepts, and which is spread by later commentators."

(J. Monod)

"Teleology is like a mistress to a biologist: he cannot live without her but he's unwilling to be seen with her in public."

(J.B.S. Haldane)

Preliminarii. Infinit mai complexă decît mintea umană—pe care a produs-o și pe care o conține—realitatea poate fi percepută prin simțuri, analizată și cercetată pe calea proceselor experiențiale de toate felurileoperate cu ajutorul unor metode și instrumente în acest scop construite-, apoi cugetată prin gîndire și redată în modalități lingvistice adecvate și potrivite relației dintre realitate și gîndire.

Tinzînd să reflecte acurat realitatea, știința obține cunoștințe și le organizează sistematic, pe baza unor principii raționate, în relație cu starea realității şi cu pozițiile acelor cunoștințe în sistemul ajustabil al gîndirii umane. În acest mod încearcă ea să înțeleagă esențele și să explice și fenomenele cercetate și, eventual, să le cuantifice-deopotrivă spre a le ierarhiza și prevedea. Iar forța cu care acționează și calitatea certitudinilor pe care le obține provin din limitele ei.

Nefiind egala realității-ci doar un proces, o cale și un instrument generat de o infimă parte a aceleia-, știința nu se poate aplica tututor entităților și proceselor realității, și cu atît mai puțin celor care scapă cunoașterii umane a realităţii-cu deosebire a celei științifice. Ea nici nu este absolută și nelimitată, și nici nu poate fi împlinită ca urmare a supunerii realităţii la prelucrările gîndirii-care, adesea, cerne totul prin sita deformatoare, întocmită din felurite considerente umane. Cu asta se ocupă filozofia și teologia, etica și morala.

Avînd a se ocupa doar cu ceea ce se află în sfera demonstrabilului-nu cu entitățile de rang abstract, absolut și de ordin subiectiv, ci cu cele concrete, relative și obiective-, spre a nu-și pierde atributele și a eșua în domeniile speculative, cercetarea științifică folosește metode și instrumente verificate și valide, pe care le aplică obiectelor cunoașterii, căutînd cauzele (naturale ale celor naturale) și urmărind rezultate care să reflecte fidel starea realității.

De aceea, căutarea științifică nu începe cu vreun moment de dinaintea apariţiei materiei (a cărei cunoaștere știința pare a o putea gestiona), ci abia de acolo are a pleca. Prin urmare, spre a se apropia treptat

*Adresă de corespondență: algafton@gmail.com. 
de aflarea a ce și cum este realitatea, știința este obligată mai degrabă să caute a afla succesiv ce nu este și cum nu funcționează o entitate. Avînd nevoie vitală de abordarea negativă—chiar în ciuda lui Aristotel, a filozofilor și a logicienilor-, ca de un pas necesar și constant pe calea înțelegerii realității, cuprinderii și orînduirii cunoștințelor, procesul științific nu se poate lipsi de continua segregare a elementelor realității, de neobosita rafinare care înlătură zgura reflexiv-intuitivă şi de optima precizare ce ajustează conceptele la chipul realității. Operat prin punerea la lucru a tuturor perspectivelor avînd potențialul de a oferi cunoaștere științifică, un astfel de parcurs necesită imperios respectarea realității și strunirea simțurilor, gîndirii și limbii.

Teleologie și știință. La un moment dat, orice demers științific poate ajunge în punctul în care pare a se afla la începutul tuturor lucrurilor, acolo unde realitatea materială nu-și mai poate afla resursele și principiile în sine. Această stare îl face pe om să caute o formă de energie pură, infinită și externă, un primum movens, în ordinea aristotelică a inducției. Întrucît întemeierea lumii pe un principiu imanent sau transcendent, cumva orînduitor, pare a constitui o necesitate inevitabilă și inexorabilă, dincolo de Dumnezeul deopotrivă imanent și transcendent al teiștilor, de cel doar imanent al panteiștilor şi de cel doar transcendent al deiștilor, toată știința umanității este străbătută de grade și ipostaze de finalism.

În chipul cel mai firesc, dezvoltarea și maturizarea științelor au adus cu sine laicizarea lor. Natura domeniilor, a cercetărilor şi a descoperirilor, metoda empirico-inductivă și modalităţile de conceptualizare și de raportare a omului la lume - pe care toate acestea le-au dezvoltat - au stimulat trecerea de la explicaţiile prin cauzele formală și finală la cele prin cauzele materială și eficientă. Ca urmare a acestei revoluții, știința a fost eliberată de teologie și de religie, și a început în mod firesc să-și caute în sine principii de existență și de acțiune, precum și căi de dezvoltare proprii-lucru îndreptățit și confirmat de faptul că multe explicații nu aveau nevoie de factori din afara realității cercetate. Concomitent, însăşi teleologia începe a ieși de sub imperiul teologiei (căruia nu îi aparținea în mod esențial și natural, așa cum nu-i aparțineau religiei nici celelalte clase de ancilla - fie științe, fie metode, fie instrumente), consecința evidentă fiind diminuarea ponderii explicațiilor ce făceau apel la teologie și ameliorarea celor care stăteau sub perspectiva teleologică.

Pe de o parte, separată de religie, știința a dobîndit teren, dezvoltarea ei oferind roade tot mai benefice. De cealaltă, apelul la teleologie nu a fost complet abandonat, ci redus la nivele rezonabile. Aceasta întrucît teleologia nu era o perspectivă eronată în sine, ci una care, decurgînd din aceeaşi rădăcină precum știința, putea fi deformată de tendința de a cunoaște și de a explica, și, precum orice altceva și precum însăşi știința, putea fi folosită în mod eronat și abuziv. De aceea, în secolul XX, continuînd gîndirea mărețului secol XIX și considerînd că știința poate doar să descrie lumea, nu să o și explice ca și cum totul ar fi lipsit de scop, alături de mulți alții, L. Wittgenstein va considera că perspectiva teleologică rămîne greu de ignorat.

Antiteleologie. Neavînd neapărat rădăcini teologico-religioase, gîndirea teleologică este deopotrivă mai complexă, mai nuanţată și mai sistemică decît o prezintă adversarii acesteia, și, totodată, mai puțin imperioasă decît o prezintă adepții acesteia, atunci cînd—și unii, și ceilalți-se situează pe poziții exclusiviste.

Cu toate că teleologia începuse a învăța să nu se mai coreleze cu speculațiile teologice și metafizice, iar ponderea ei explicativă scăzuse proporțional cu creșterea gradului de științificitate al explicațiilor, începînd cu ultimele două decenii ale secolului XIX și continuînd în întreg secolul XX se înregistrează o reacție excesivă față de aceasta. Încă din timpul vieții lui Darwin, cercetătorii și gînditorii care treceau știința prin site ideologice aparent materialiste, și care își construiseră o credință alimentată de idealuri avînd temelii vechi de cel puțin două sute de ani, au văzut în explicaţia darwinistă prilejul ideal și oportun de a lichida perspectiva finalistă—care bloca avansul gîndirii ideologice pe care o propagau. Temelia și stindardul acestea au fost alese în pofida faptului că însuși Darwin, care își întemeiase explicaţia pe acțiunea factorilor fizico-chimici și interacționali, era perfect conștient că nici această explicație nu este fără cusur, nici nu le poate înlocui cu totul pe celelalte-pe cea lamarckiană, de pildă, din care provenea—și nici nu soluționa altceva decît chestiunea evoluției materiei vii, prin producerea și diversificarea speciilor. Mai mult, cu demiurgică înțelepciune, Darwin înțelegea nu doar că explicația sa are nevoie de completări și 
de argumente, dar și că—nemetaforizată—ea nu putea coborî sub pragul la care se referea inițial—cel al materiei vii.

Asupra acestei situații evidente și de neignorat avertizaseră L. Agassiz: „Lumea a apărut într-un fel sau în altul. Marea întrebare este cum a generat viața, iar teoria lui Darwin, precum toate celelalte încercări de a explica originea vieții, este pur și simplu conjecturală” și J.A. Shapiro: „Pentru acei oameni de știință care o iau în serios, evoluția darwiniană a funcționat mai mult ca un sistem de credință filozofică decît ca o ipoteză ce poate fi supusă testării științifice”.

Lucrul a fost posibil întrucît cei angajați în lupta antiteleologică au preluat de la Darwin elemente valorificabile ideologic (acțiunea oarbă a selecției naturale, concept pe care Darwin îl nuanțase și relativizase, însă), au simplificat aspecte (selecția naturală ca factor unic, deși Darwin subliniase apăsat și explicit că selecția naturală este factorul central, dar nicidecum singurul) și mai ales au eliminat aspecte-lamarckiene sau nelamarckiene-, neconcordante cu ideologia și cu țelurile lor: rolul întrebuințării și neîntrebuințării structurilor, pe care, aproape la tot pasul și în întreaga sa operă, Darwin își întemeiază raționamentele de cea mai mare greutate pentru fundamentarea și argumentarea explicaţiei sale; transmiterea trăsăturilor dobîndite, în care Darwin credea într-atît încît a inventat o teorie care să explice fenomenul; ideile referitoare la suprapopulație și concurența inter- și intraspecifică, care constituie pilonul genitorial și fundamental al chiar ideii de selecție naturală; evoluția direcționată și convingerea că există „general purposes of life"(Darwin, 1875). Eliminarea acestora și înlocuirea lor cu altele, apoi absolutizarea unora şi bagatelizarea altora-totul în răspărul convingerilor și avertismentelor lui Darwin-, pot produce o teorie coerentă şi dotată cu atribute credibile, însă rezultatul nici nu poate fi numit darwinism, nici nu i se poate afirma esența ori extracția darwinistă, în primul rînd întrucît neagă exact darwinismul.

Modificînd explicația darwinistă și amplificîndu-i impulsul cu o inimaginabilă energie—pe care doar ideologiile o dețin și pe care știința nu o poate produce niciodată la o asemenea intensitate-, neodarwiniștii (a căror doctrină avea ca unică sursă, temei crucial și scop perpetuu: antiteleologia) au construit o mașinărie destinată lichidării perspectivei finaliste (prin abandon, eliminare și spulberare). Alimentată de mize ideologice întemeiate pe o dogmă construită ad-hoc și folosind metode și instrumente speculative, această maşinărie a produs și utilizat o combinație de argumente (logice, analogice etc., dar mereu sofistice), prin care s-a încercat construirea unei explicații infailibile, care să le înlocuiască pe toate celelalte, care să atingă autosuficiența și să ducă la împlinirea dezideratului cerut de fraza lui Marx: „Filozofii nu au făcut decît să interpreteze lumea în diferite moduri, important însă este a o schimba”.

Însușindu-și imaginea științifică a lui Darwin—una pozitivă și progresistă—, dimpreună cu elemente de terminologie (variație, adaptare, evoluție, selecție naturală etc.), neodarwiniștii au confecționat o idee simplă și populară: totul apare, există, funcționează, se dezvoltă și evoluează în baza unei (oarbe) loterii genetice, în condiții de deplină egalitate de șanse și de liber arbitru. Totodată, au lăsat deoparte elementele de complexitate, nuanțele procesuale și incertitudinile oricărui proces de cunoaștere științifică autentică. Rezultatul a fost un construct cu aparențele autosuficienței și capacității de a găsi perpetuu în sine argumente în favoarea propriei consolidări și contraargumente de apărare și de atac. Mai mult, era un construct refractar la orice schimbare (fie și adaptativ-evolutivă) și rezistent chiar la progresele cunoașterii științifice - cel puțin pînă la un anumit prag destul de ridicat. Sub acest aspect, este de maximă relevanță faptul că, după ce a apărut prin preluarea și modificarea radicală a darwinismului, neodarwinismul a cunoscut mai multe pseudoetape-postneodarwinism, sinteză evoluționistă, sinteză evoluţionistă modernă și sinteză evoluționistă modificată—, care nu sînt nimic altceva decît avatariile aceleiași ideologii care, o dată fabricată, a căutat cu programatică tenacitate să se conserve prin înghețarea filonului de gîndire inițial, conceput ca inert la orice altceva-desigur, implicit la progresul cunoașterii științifice. Acest ultim efect a fost asumat de către neodarwiniști, care au arătat că nici un preț nu era prea mare pentru ei, atît timp cît nimicirea finalismului echivala cu instaurarea unei dominații absolute. 
Mozaicul conceptual și retorica discursivă. Filonul teleologic este atît de profund uman încît o remodelare din străfunduri a gîndirii-care să-l elimine cu totul-poate genera efecte incalculabile, întrucît prezența finalismului asigură dăinuirea mai multor modalități de a gîndi și de a soluționa probleme, a unei gîndiri care poate progresa prin negarea a orice, mai puțin a libertății de a gîndi în chipuri multiple. $\mathrm{Cu}$ toate acestea, ofensiva antiteleologică_purtată cu maximă strădanie și cu totală dedicare—a vizat dispariția ideii de teleologie și a întregului limbaj aferent.

Începînd cu August Weismann și pînă dincolo de Ernst Mayr-luați ca repere și urmați mai mult sau mai puțin fidel și nuanțat de numeroși naturaliști și filozofi-, știința secolelor XIX-XX a fost constant obsedată de găsirea unor argumente antiteleologice irefutabile, proces care a dus la încercarea de desființare a oricărui fel de proliferare a oricărei alte poziții-de la aderenții declarați ai concepției teleologice, trecînd prin cei care observau cu onestitate și probitate că unele aspecte teleologice nu pot fi contestate întrucît nu li se poate demonstra caracterul iluzoriu, și nici nu pot fi înlocuite $\mathrm{cu}$ aspecte contrarii, și încheind cu cei antiteleologizanți, dar care nu erau neodarwiniști.

Războiul a fost dus cu toate mijloacele. Mai întîi s-a întreprins o vastă activitate de edificare a unei complexe construcții conceptuale, care să o înlocuiască și să o arunce în caducitate pe cea teleologicăîn chip natural durată de-a lungul mileniilor. În acest scop a fost ridicată o întreagă schelărie ideatică și lingvistică, imaginînd şi redefinind entități, procese și relații, aşezînd pe rang de adevăr incontestabil aserțiuni nedemonstrate sau discutabile, adesea consecințe ale unor distincții și raționamente torticulareorientate de scopul avut în vedere. Concomitent, s-a operat în direcția desființării oricăror argumente ale celor de pe altă poziție. Șirul de bătălii s-a purtat pe multe tipuri de front, cu tehnici, strategii și instrumente elaborate, dar lipsite de scrupule, în general fără prea mult respect pentru adversar. Acesta a fost aproape mereu ridiculizat ca prizonier iremediabil al unor prejudecăţi, misticisme sau rătăciri, ori doar acuzat de incapacitatea de a înțelege și accepta raționamente și dovezi calificate ca irefutabile și de la sine evidente ca atare, respingîndu-i-se scurt și de plano atît argumentele, cît și contraargumentele. La rîndul lor, argumentele și contraargumentele neodarwiniștilor erau mereu axiomatizate, supralicitate, circulare și contrafactuale, preferatul find ignoratio elenchi. Practic-precum în cazul (neo)lamarckienilor-cu toate mijloacele, au fost descurajați, discreditați, repudiați și pedepsiți ca eretici toți cei care au dat vreun semn ce putea fi interpretat ca unul de neaderență la doctrina și la dogma neodarwinistă și antiteleologică.

Schița care urmează oferă o imagine a situației din ultima parte a secolului XX, adică din etapa de apogeu—cea în care argumentația antiteleologică a ajuns pe propriile culmi, sub toate aspectele.

Probabil că unul dintre cei mai reprezentativi cercetători care au luptat sub drapelul neodarwinismului și antiteleologiei a fost E. Mayr. Subliniind lucruri pe care nimeni nu le-a negat, și anume că între scop și cauzalitate există o relaţie liberă și că scopul nu se confundă cu starea „finală” a unui proces, E. Mayr încearcă să construiască și să apere poziția precum înaintaşul său, A. Weismann, adică prin toate tacticile deja semnalate, sprijinindu-se mai cu seamă pe cele discursive, operînd numeroase segregări semantice și izolînd concepte pînă la dispariția unora și la crearea altora, prin amalgamare. Astfel va proceda după ce va susţine că termeni precum teleologie și teleologic au fost aplicaţi la fenomene dintre cele mai diverse, fiind definiți și folosiți felurit, eronat, confuz.

Sarcina redefinirii conceptelor sensibile constituie o strategie practicată de întreaga descendență weismanniană, prilejul fiind creat în vederea segregării și regrupării fenomenelor în clase arbitrare și convenabile celui care le identifică și definește spre a reconstrui prin cuvînt realitatea și conceptele, în vederea creării unui instrumentar unificat, care să orienteze modalitățile de conceptualizare a realității în conformitate cu finalitățile și cu dogmele neodarwiniste.

Oarecum ironic_-dacă implicațiile nu ar fi fost devastatoare pentru parcursul cunoașterii științifice一, faptul arată prin sine caracterul indispensabil pentru om, al „zgomotului” teleologic, și contribuie la a-i atesta temeiurile—cel puțin din mintea umană, dacă nu și din realitate.

Înainte de a segrega conceptele 'teleologie' și 'teleologic', pe urmele lui Jacques Monod, E. Mayr reia conceptele care ar fi trebuit să ofere temeiuri dogmei antiteleologice, adică 'funcție' și 'program'. Distincția 
dintre cele două ar fi că funcția se poate referi atît la un proces fiziologic, cît și la un rol biologic al unei structuri sau activități (funcția picioarelor iepurelui este locomotorie, dar rolul biologic al acestei facultăți poate fi de a scăpa de prădători) - doar cea de-a doua accepțiune putînd căpăta valențe teleologice. La rîndul său, programul este definit ca o informație codată sau anterior rînduită, care controlează procesul, conducînd către scop. Programul ar conține nu doar schița scopului, ci și instrucțiunile de folosire a schiței, fiind ceva material și preexistent iniţierii procesului reglementat—un set de instrucțiuni, iar nu o descriere a unei situații. Totodată, întrucît existența programului este inferată din manifestările comportamentelor sau activităților programate, funcționarea acestora permite achiziția de informație, cu modificări structuralfuncționale în consecință (Monod, 1972; Mayr, 1974).

Atît distincția dintre funcție și program, cît și cea paralelă, dintre natural şi artificial—care are în vedere structuri funcționale, pe de o parte, autoasamblate, autoreproductibile și avîndu-și principiile de dezvoltare în propriile funcțiuni, iar de cealaltă, asamblate și reproduse cu aport energetic și planificare externe - sînt constructe orientate de scopul demonstrației care pregătește degajarea anumitor elemente dintr-o realitate mult mai complexă decît ceea ce va rămîne din ea. Acest fapt se observă în cele ce urmează.

Continuînd pe urmele lui J. Monod și fiind atent cu deosebire la cei care invocă forțele supranaturale sau un principiu vitalist, E. Mayr arată că unele obiecte ale lumii fizice sînt înzestrate cu capacitatea de a se schimba, proces petrecut în strictă conformitate cu legile naturii, care interacționează cu proprietăţile intrinseci ale obiectului asupra căruia acționează. De pildă, un corp de mărimea Pămîntului, prins în forța gravitaţională a Soarelui, ajunge în mod necesar sferic, strict în virtutea relației dintre legile cărora li se supune și trăsăturile sale. Dacă potențialul este folosit, aceste procese se finalizează, dacă intervine o piedică externă (precum gravitaţia ori entropia), ele sînt stopate, dar nici într-un caz, nici în celălalt, efectul nu se produce în virtutea unui scop preexistent. Pe urmele lui Aristotel, atît J. Monod, cît și E. Mayr fac o primă segregare a conceptului 'teleologic' și numesc o astfel de direcționare automată teleomatică (Monod, 1972; Mayr, 1974, 1988, 1992).

Cea de-a doua segregare este făcută arătînd că entități precum vietățile, ale căror structuri funcționale dețin un program (cum este codul genetic), acționează desfăşurînd un proiect. Acest program codifică și reglementează comportamentul—către un efect final sau de termen. O astfel de acțiune, reductibilă la cauze fizico-chimice, este numită teleonomică (Pittendrigh, 1958).

Referindu-se la mersul automat al evoluției, pe un curs al perfecționării, totodată înțelegînd că structurile organizate (precum organismul) implică orientarea către un efect, termenul născocit de către Colin Pittendrigh este un produs al tentativei de a distinge și separa 'efectul' de 'intenție'. El este parte a încercărilor de eliberare a științei de teleologismul aristotelic și de redirecționare a limbajului metaforic și teleologic.

Socotind procesele teleonomice, pe cele teleomatice și adaptarea prin selecție naturală ca fenomene strict materiale, E. Mayr le scoate din sfera teleologiei. Cu toate acestea, neputînd să nu recunoască faptul că și aici există procese și activități orientate în mod clar către un scop, el va susține că acest lucru nu necesită implicarea forțelor supranaturale deoarece scopul este deja codificat în programul care guvernează acele activități. Ca întotdeauna, selecția naturală—văzută ca proces de optimizare, dar nu unul orientat către un scop, ci care se petrece în virtutea inerției, abia rezultatul arătînd dacă schimbarea aceea a contribuit sau nu la adaptare-este considerată a fi o explicație satisfăcătoare la evoluția organică, astfel încît să facă inutilă invocarea vreunor forțe supranaturale. (De altfel, chestiunea este atît de complexă încît chiar acceptînd că procesele din lumea anorganică, orientate către un final, se datorează pur și simplu acțiunii legilor naturii, posibilitatea de teleologie tot nu dispare cu desăvîrșire, deoarece, după cum vom vedea, nu divinitatea este marele susţinător al teleologiei.)

În cele din urmă, subliniind că astfel de procese nu funcționează în virtutea unui scop viitor, îndărătul lor neexistînd vreo legătură cauzală, și rămînînd ferm pe poziția antiteleologică și antivitalistă, E. Mayr acceptă că rămîn în discuție destule aspecte încă nedeslușite, științei actuale fiindu-i extrem de greu să 
Francisc Gafton

explice teleologia, care încă nu poate fi negată categoric și pînă la capăt în mod argumentat (Mayr, 1974, 1988, 1992).

Cele zece porunci. Încercînd să ofere o călăuză lămuritor-edificatoare și întăritor-fixatoare a acestor idei, E. Mayr își sintetizează poziția enunţînd zece afirmații de credință prin care trasează căi de urmat, obligatorii pentru gîndirea antiteleologizantă prezentă și viitoare. Întrucît biologii au mare nevoie de elemente de teleologie-ideea că cercetarea biologică se sustrage rezultatelor fizicii este destul de curentă printre teoreticienii științei biologiei, printre filozofii științei și printre biologi, deși înșiși fizicienii acceptă că există grade de nelinearitate a legilor fizicii-, E. Mayr concede că, pentru biologi și în biologie, valoarea euristică a problematicii teleologice o face să fie un instrument puternic în cercetarea biologică, de la nivel submolecular la nivel social. De aceea, el acceptă ca legitimă utilizarea limbajului considerat teleologic, dar adaugă că faptul nu implică nici respingerea explicației fizico-chimice, nici explicația non-cauzală.

Apoi, el arată că parțial sau total, programele sînt produsul selecției naturale, cele a căror orientare către un scop este controlată de un program fiind teleonomice, iar cele care ajung la un final cauzat de legile naturii, iar nu de un program, fiind teleomatice. Diferențiind net între nivelele de complexitate caracteristice naturii vii, pe de o parte, și celei inanimate, de cealaltă, E. Mayr arată că comportamentul teleonomic (adică programat) apare doar la organisme (și la aparatele construite de către om), după care adaugă că explicația teleonomică este strict cauzală și mecanicistă, deci nu poate servi adepților concepțiilor vitaliste. Aceasta este cea mai abilă modalitate de argumentare și blocare totodată, prin care: a) se construiește un concept adecvat propriei construcții ideatice; b) se monopolizează acel concept; c) li se interzice sau li se blochează adversarilor accesul la respectivul instrument; d) se lasă liberă doar poziția nedemonstrabilă sau în mod evident imposibil de susținut cu argumente științifice-totul spre a-i lipsi pe ceilalți de capacitatea și chiar de posibilitatea de a da un răspuns acceptabil.

În cele din urmă, E. Mayr susține că este lipsit de îndreptăţire să se descrie procesele sau tendințele evolutive ca direcționate către un scop (adică în chip teleologic), selecția răsplătind fenomene deja petrecute (mutaţii, recombinări etc.), fără a plănui viitorul—cel puțin nu într-un chip anume. Întrucît toate acestea nu rezolvă chestiunea antiteleologică, în cel mai weismannian spirit-în care ceea ce nu corespunde concepției, trebuie negat sau amînat-el încheie arătînd că problema legitimității aplicării termenului teleologic la sistemele adaptative sau funcționale staționare necesită analize mai atente (Mayr, 1974), deocamdată fiind inadmisibilă.

După cum se observă, modalitatea weismanniană de a gîndi și proceda îi face pe neodarwiniști să opereze distincții lipsite de temeiuri științifice, spre a recupera elemente indispensabile, dar aflate în sfera conceptului 'teleologie', sau să susțină că adevărata caracteristică a comportamentului direcționat către un scop nu este existența unui mecanism care îmbunătățește precizia cu care este atins scopul, ci existența mecanismului care iniţiază, adică provoacă acest comportament direcționat către un scop, ori că selecția naturală este un proces de optimizare, dar nu este orientată către un scop, abia după ce se petrece urmînd să se arate dacă schimbarea respectivă contribuie la adaptare.

Întregul set de definiții este o construcție anticipativă, prin care teleologia este despicată, în speranța golirii sale de orice esență. Pe de o parte, separațiile au rolul de a dovedi că viul apare în consecința unor procese spontane de autoconstituire morfologică și de autoreproducere, ale căror principii se află în sine—adică în programul conținut și pe a cărui bază se structurează, funcționează, reproduce, dezvoltă și evoluează viul一, ferite de efectele acțiunilor externe și de retroacțiuni. De cealaltă, reducînd procesele teleomatice la statutul de procese supuse acțiunii legilor naturale, iar pe cele teleonomice la procese supuse acțiunii fizico-chimice, se speră că gîndirea teleologică va dispărea.

Dar dincolo de toate acestea, faptul de maximă semnificație—caracteristic tuturor neodarwiniștilor antiteleologizanți-este că modalitatea de a raționa și de a purta lupta este profund teleologică.

Mutație și adaptare. Pe acest fond, o chestiune importantă și de neocolit se referă la caracterul determinat sau nedeterminat al mutațiilor și adaptărilor. Deși au pondere mai degrabă neînsemnată în rîndul eveni- 
mentelor cu impact genetic și una încă şi mai mică pentru rezultatele selecției, mutaţiile impresionează atît datorită consecințelor negative pe care le generează, cît și datorită impredictibilității lor. Supralicitată de un opozant parțial al lui Darwin, și anume Hugo de Vries, mutația a fost folosită ca explicație preferatăadesea unică—de către neodarwiniști. Susținînd că mutaţiile se produc, se manifestă și sînt selectate absolut întîmplător și imprevizibil, ei absolutizează ereditatea genetică și indeterminarea. De aceea, apariția unei relații de corespondență între o mutaţie și efectele ei era considerată rod al unei pure coincidențe.

Astfel, arătînd ferm și repetat că funcția depinde de structură, apoi de rolul proteinei modificate, de interacțiunile la care participă și de reacțiile pe care le catalizează, Monod (1972) afirmă că aceste fapte sînt lipsite de legătură cu mutaţia în sine și cu cauzele ei imediate sau îndepărtate. Pe acest temei, el concluzionează că între evenimentele care provoacă sau permit o eroare de replicare a mesajului genetic și consecințele sale funcționale nu există nici o relație.

Blana ursului polar. Apăruți după ce o ramură a urşilor bruni a rămas izolată și a ajuns să trăiască în condiții geo-climatice nemaiîntîlnite de aceștia, urșii polari au căpătat o blană diferită de a strămoșilor lor, cît se poate de compatibilă cu solicitările mediului în care trăiesc. Raționamentul neodarwinist care explică apariția acestei blăni-care nu s-ar datora adaptării la mediu a organismelor, ci unui miraculos lanț de întîmplări perfect coordonate între ele şi cu mediul—se desfășoară imaginînd evenimentele conform următoarei succesiuni de pure întîmplări: a) genele (cel puțin două) care produc melanină suferă o mutație; b) care duce tocmai la producerea de fire de păr lipsite de pigment; c) faptul afectează destul de multe exemplare; d) de ambele sexe. Apoi urmează fenomene ce țin de adaptare și de selecție, singurul aspect solid al teoriei neodarwiniste, preluat din darwinism, dar absolutizat: întrucît în acel mediu organismele deținătoare cunosc o creștere a capacităților de a răspunde la solicitările mediului, blana albă constituie un avantaj; acest fapt sporește șansele de supraviețuire ale exemplarelor mutante, în comparație cu șansele tipului sălbatic; totodată, împerecherile dintre urșii albi, concomitent cu scăderea încrucișărilor dintre cele două tipuri, perpetuează mutația și rezultatele ei, ceea ce sporește numărul exemplarelor mutante, comparativ cu cel al celorlalte. Așadar, apariția întîmplătoare a mutației care a adus cu sine o blană mai potrivită și mai adaptată la mediu—comparativ cu a exemplarelor care nu suferiseră mutaţia—, a sporit șansele de supraviețuire și reproducere a exemplarelor mutante, încît, treptat, ca urmare a acțiunii selecției naturale, urșii cu blana albă au ajuns să-i elimine și înlocuiască pe cei bruni.

Examinînd îndeaproape o astfel de narativă devine limpede că ea nu are posibilități de a corespunde cu realitatea proceselor din natură. În condițiile în care trăsătura în discuție este poligenică, iar mutațiile nu au forța de a produce modificări de mare amploare, este greu sau aproape imposibil de acceptat că mutaţia ar fi afectat blana de pe întregul corp și că s-ar fi manifestat prin apariția formei finale, iar nu doar pe o porțiune care să se decoloreze - cel puțin în prima etapă. Dar o astfel de mutație parțială ar fi avut șanse infime de a fi luată în seamă și reținută de selecția naturală. Mai mult, dacă este rezultatul imprevizibil al purei întîmplări, lipsit de orice legătură cu necesitatea sau cu utilitatea structural-funcționale, atunci orice posibilitate este la fel de realizabilă, fiind foarte probabil ca mutația să se petreacă în direcțiile tuturor nuanțelor la care participă melanina. Cu siguranță că multe dintre aceste încercări oarbe ar fi fost respinse de selecția naturală, dar la fel de sigur este că pe unele selecția le-ar fi tolerat. Altminteri ar însemna că presiunile selective sînt extrem de mari-ceea ce, de regulă, nu se constată. Aceasta întrucît, înainte ca presiunile selective să atingă teribil de ridicata cotă necesară unui asemenea grad de eliminare a organismelor rezultate ca urmare a loteriei mutațiilor, la nivelul organismelor se activează cu putere mecanismele adaptative, prin care se răspunde adecvat la solicitările mediului, viața acționînd în propriul beneficiu, care înseamnă prezervare și continuare (supraviețuire și reproducere). Acesta este faptul care, în ceea ce privește viaţa, se constată întotdeauna şi negreșit.

De aici se înțelege că acceptarea scenariului neodarwinist implică în mod necesar asumarea unui șir perfect de coincidențe oportune în natura, măsura, modul, momentul și succesiunea lor: întîmplarea 
face să se producă o mutație, care este exact cea potrivită acelui mediu, în proporția optimă pentru buna relație acesta și optim valorificată fenotipal; apoi întîmplarea face ca mutația să se producă la suficient de multe exemplare (încît să aibă șanse de supraviețuire) și la ambele sexe (încît să aibă șanse de reproducere). Iar peste toate, selecția naturală, forță solitară, ineluctabilă şi de mărime copleșitoare, operează conform propriilor rigori determinate, asupra unui domeniu al produselor purei întîmplări, astfel încît rezultatul final deține atîta optimitate încît unora le-ar părea planificat sau măcar urmărit succesiv.

Toate acestea contravin flagrant chipului în care se petrec lucrurile în realitatea naturală. Apoi, ele pot fi acceptate ca atare numai și numai concomitent cu respingerea oricărui determinism, care, deși nu este orientat de un presupus scop preexistent, are proprietatea de a canaliza și orienta dezvoltarea structurilor funcționale conform relației dintre proprietățile lor și dominantele mediului, astfel încît evenimentele să se desfășoare pe traiectoriile unor rețele cauzale.

Negînd vehement relația dintre evoluție și solicitările mediului, antiteleologizanții consideră că presiunile selective pe care le exercită condițiile externe asupra organismelor nu sînt legate de performanțele „teleonomice” caracteristice speciilor, ceea ce înseamnă că, interacționînd cu mediul, organismul „alege” interacțiunile și determină natura și orientarea presiunii selective pe care o suportă (Monod, 1972). De fapt, lucrurile stau întocmai invers: organismul nu alege, ci răspunde: a) interacțional la natura și la parametrii presiunilor, și b) proporțional cu complexitatea și cu autonomia pe care le deține. Singura modalitate de influențare pe care o are acesta decurge din compatibilitatea răspunsului cu natura și trăsăturile solicitărilor-răspuns cu șanse de adecvare proporţionale cu complexitatea și autonomia organismului. Adică variabilitatea și adaptabilitatea nu constituie accidente ci potențiale folosite ca răspuns.

Este ca și cînd s-ar afirma că existența firească a sistemelor presupune în mod natural că aberațiile și disfuncțiile apărute în funcționarea lor sînt echivalente cu stările structural-funcționale normale. Adică, în anumite zone, condiții și momente ale existenței funcționale ale mediului, şi în concertul componentelor sistemului-sau pur și simplu sub orice condiție existențială-, aberațiile şi disfuncțiile îşi află în chip firesc (sau doar cumva) locul, utilitatea şi rostul. Adică sistemele ar fi anomalice astfel încît toate anomaliile și disfuncțiile care apar nu sînt rodul erorilor de sistem—care nu și-ar datora existența stabilității și variabilităţii limitate—, ci constituie părți ale normalităţii, deci existența și devenirea sistemului presupune asimilarea și perpetuarea aberațiilor și disfuncțiilor, a anormalității. În acest caz, selecția naturală nu mai este filtrul evoluînd, care promovează ceea ce este viabil (sub toate aspectele) și elimină ceea ce dăunează funcționării optime și reproducerii în continuare a sistemelor, ci doar un dispecer involuînd, care plasează erorile și le asigură existența (într-un sistem tot mai puțin rezultat al devenirii proprii și tot mai mult înlocuit de o genealogie a aberațiilor și disfuncțiilor, desigur).

În sfîrşit, cu toate că adaptarea—ca rezultat—este o stare a posteriori, ca proces, ea constituie o modalitate de a acționa direcționînd către un scop. Desigur, scopul este supraviețuirea și, eventual, reproducerea, acelui organism, iar modalitățile concrete țin de orientarea exercițiului funcțional al componentelor aceluia, în relaţie cu condițiile mediului concret.

Mișcările materiei. Evenimente precum mișcările și coliziunile de particule par aleatorii, însă ele se supun acțiunii unui set de factori și de acțiuni-studiate și cuprinse în ceea ce se numește legile fizicii-și se produc în consecință, generînd ceva previzibil, numit entropie (parte esențială a principiului al doilea al termodinamicii).

Constituind o probă indirectă a existenței atomilor și moleculelor, mișcarea browniană, de pildă, se referă la deplasarea aparent întîmplătoare a particulelor suspendate, cu efectul direct al ciocnirii lor și cu cel indirect al modificării fluctuante a vitezei și frecvenței ciocnirilor. Cu toate că evenimentele interacționale prin care trece o astfel de particulă nu pot fi subsumate unui tipar-de unde impresia de „aleatoriu”-, pînă și acest caz de mișcare poate fi descris prin aplicarea de modele probabilistice. 
Curenții oceanici. La scara la care se desfăş̧oară și acționează, curenții oceanici prezintă parcursuri destul de bine definite, date de acțiunea conjugată, în diferite grade, a mai multor factori avînd acțiuni și efecte generale și contextuale - conjugate și interrelaționate, constante și variabile. Dar aceeași curenți pot fi priviți succesiv la nivele tot mai detaliate, unde apar felurite variații concordante cu respectivele nivele și devenite importante în cadrul acestora. De pildă, curentul oceanic este generat, întreținut și modulat de: a) mișcarea Pămîntului (care ține de starea forței acestuia, la rîndul ei dependentă de relația dintre masă și viteza de deplasare, legată de faptul că se apropie sau se îndepărtează de Soare) și de starea sa gravitațională (care nu este aceeași în oricare moment); b) geografia oceanului (care se modifică, ceea ce la un anumit nivel poate conta, iar la altul nu); c) particularităţile apei (care includ temperatura, vîscozitatea); d) interacțiunea cu alți curenți; e) prezența în apă a unor corpuri (insule, vietăți marine, artefacte etc.) ș.a.m.d.

La diferite nivele și cu implicații de diferite grade, acești factori au potențialul de a afecta previzibilitatea de dinamică și de efect, a curenților oceanici, dar acest fapt nu înseamnă că rezultatele sînt lipsite de cauze sau că ar fi evenimente aleatorii.

Zooplanctonul. La rîndul său, doar aparent rătăcitor-precum planetele-, zooplanctonul are o existență determinată de acțiunea unei multitudini de factori complex întrețesuți și care se influențează între ei, fiecare dintre aceștia fiind determinat de alți factori, într-o înlănțuire ce pleacă de la curenții oceanici și ajunge la nivel atomic, după ce include acțiunile acelor vietăți, inclusiv ale însuși zooplanctonului autopropulsat. Considerînd zooplanctonul din întregul ocean planetar, doar pe cel dintr-un anumit ocean, ori doar un exemplar din fiecare dintre cele cîteva tipuri de zooplancton, se va putea observa că acțiunile factorilor au efecte diferențiate, atît ca poziție și pondere, cît și ca importanță. De aceea, cu toate că, pentru individ, luat ca entitate, poate fi important ce, unde, cînd, cît și cum anume se petrece cu el, pentru întreg și pentru evoluție este lipsit de importanță ce se petrece cu individul. Desfăşurată în virtutea funcționării Planetei, producția de fitoplancton asigură existența zooplanctonului, care participă la funcționarea verigilor superioare și în cele din urmă a Planetei. Deși neimportante în sine, evenimentele prin care trece un krill pînă ajunge să moară de bătrînețe sau în sistemul digestiv al unei balene cu fanoane sînt determinate în rețele cauzale complexe, necesare în ordinea funcționării legilor fizico-chimice ale Naturii, lipsite de necesitate sau scop din perspectiva lor, a krill-ului, a oceanului sau a prădătorilor, dar participînd la necesitatea existenței funcționale a claselor succesive de întreg.

Alea iacta est. $\mathrm{O}$ aruncare de zar pare a fi aleatorie în cel mai înalt grad. Cu toate acestea, evitînd impresia grăbită și întîmplătoare, analiza migăloasă scoate la iveală că la un astfel de act participă numeroși factori. Forța de prindere și de aruncare a mîinii, apoi traiectoria descrisă de aceasta, topologia zarului și a mîinii, relațiile dintre acestea, natura și efectele elementelor care determină gradul de adeziune dintre zar și mînă (de la cît de strîns este ținut între degete, la cît de lejer stă în palmă, și de la prezența, la forța de coeziune a diferitelor substanțe aflate pe suprafețele în contact), compoziția aerului (dată de proporțiile concretedin spațiul aruncării-dintre $\mathrm{N}_{2}, \mathrm{O}_{2}, \mathrm{Ar}$, alte gaze rare, $\mathrm{CO}_{2}, \mathrm{H}_{2}$ etc.), parametrii zarului (mărime, greutate, caracterul muchiilor, colțurilor, suprafețelor, gravurilor şi substanțelor care îl învelesc), apoi natura suprafeței de rostogolire sau doar de lovire și aterizare, forța de reacțiune a acesteia, existența, pe aceasta, dar şi în aer, a vaporilor, a particulelor în suspensie sau de praf și altele asemenea constituie forțe de influență care, cel puțin la începutul unei cercetări, nu pot trece neluate în seamă. Unele dintre acestea constituie constante, altele variabile, și aceasta în mai multe sensuri. Adică, teoretic, unele ar putea fi valabile pentru orice situație de aruncare a zarului (parametrii formali ai zarului sau ai suprafeței de lovire-aruncare, de pildă), în vreme ce altele prezintă grade și tipuri de variabilitate, toate cu posibile efecte de mai multe feluri. Astfel, circumstanțele aruncărilor se pot modifica în timpul unui set de aruncări: a) deși este rezonabil să se presupună că, în același loc, aerul are compoziția constantă, nu este exclusă modificarea condițiilor (de la starea vremii, la alte tipuri de „accidente”); b) aceeași persoană nu aruncă de fiecare dată neapărat cu aceeași 
forță și pe aceeași traiectorie-dimpotrivă, empiric se poate dovedi peremptoriu că acest fapt niciodată nu se petrece absolut întocmai, nici regulat, nici „aleator”. Factorii în discuție, așadar, acționează diferențiat pentru fiecare aruncare a zarului, de către aceeași persoană și în același loc, ceea ce este de natură să inducă determinări în ceea ce privește rezultatul, chiar dacă nu toți factorii au întotdeauna consecințe efective, unii contînd doar în anumite conjuncții și interacțiuni, alții putînd deveni neglijabili.

Accidens (in)separabile. Lucrurile nu stau cu totul altfel în cazul unor înșiruiri de evenimente. Este posibil ca un individ neglijent și agitat (din cauze genetice, patologice, de educație carențială, de mediu, de trai) să participe la jocul de zaruri, în timp ce consumă o prăjitură din care se scurge siropul pe covor. O mișcare exagerată face ca zarul să depășească suprafața de aruncare și să fie proiectat spre covor. Momentul în care zarul urmează să atingă covorul coincide cu cel în care, în locul căderii, se afla o furnică atrasă de sirop. Deși între unele secvențe pot fi aflate relații (antecedentele individului, starea sa de nervozitate, faptul că mănîncă neglijent, alături de căderea siropului pe covor și venirea furnicilor), în vreme ce între altele nu există (momentul în care cade zarul și cel în care o anumită furnică se află la capătul traiectoriei zarului), un astfel de lanț-—pe care, în felurite forme și grade de complexitate, oricine l-a trăit în linearitatea sa temporală—nu este complet lipsit de determinism. Mai mult, verigile sale pot deveni puncte de plecare pentru alte lanțuri de întîmplări (fie în ceea ce privește zarul, covorul, prăjitura, fie în ceea ce privește individul, membri ai familiei sale sau furnicile).

Amprentele. Întrucît apar dintr-un zigot fertilizat și apoi divizat, gemenii monozigoți dețin aceeași secvență de ADN. Deși vor avea numeroase trăsături aproape identice, amprentele lor nu vor fi astfel, ci vor fi sensibil diferite. Aceasta deoarece trăsăturile amprentelor nu sînt determinate exclusiv de factori genetici, în formarea lor fiind implicaţi factorii de mediu.

Prin aceasta-ca orice produs deopotrivă genetic și epigenetic-, amprentele vădesc nu doar capacitatea aceluiași genotip de a genera mai multe fenotipuri, ci și semnificația acestei capacități, întrucît existența ei indică o modalitate de funcționare a nivelului genetic, ca potențial care se activează și acționează interacțional cu și acomodat la mediul concret al individului deținător al respectivei constelații genetice.

Dermatoglifele se formează în timpul perioadei fetale (aproximativ între prima și a doua treime a perioadei de sarcină). Primul determinant al configurației lor este de natură genetică, prin intermediul mai multor gene (unele care se ocupă direct de ele, altele care se ocupă cu formarea pielii, a mușchilor, a grăsimii, a oaselor, a vaselor de sînge din zonă etc.) stabilindu-se parametrii creșterii celulare a întregului ansamblu (palma). Al doilea determinant este constituit de acțiunea factorilor de mediu, care determină elementele de detaliu și de nuanță ale dermatoglifelor.

Factorii de mediu sînt de natură mecanică (dintre care cel mai important este presiunea) și acționează pe diverse căi concrete (poziția și mișcările fătului în uter, rata de creștere a degetelor, presiunile și caracteristicile fluxurilor sanguin și de substanțe organice prin piele, presiunea și mișcările lichidului amniotic, vîscozitatea tuturor acestor lichide, posibilitatea ca degetele să atingă placenta), astfel determinînd trăsături particularizante în ceea ce privește înălțimea proeminențelor, adîncimea șanțurilor, distanțele dintre șanţuri, lungimile, lăţimile şi regularitatea lor, modelele curburilor etc. Pe măsura formării întrun fel a adînciturilor, continuarea acțiunii factorilor determinanți duce la stabilizarea sau la modificarea modelului care, astfel, se constituie treptat.

Deși par aleatorii ca prezență și ca acțiune, acești factori sînt determinați în raport cu ceea ce-i pune în act și determinanți în raport cu efectele acțiunilor lor-toate riguros exercitate-chiar dacă imposibilitatea analizării lor le dă aparența de imprevizibilitate.

De pildă, observarea mișcărilor mamei și fătului arată că acestea sînt stîrnite de nevoi și de stări, înrîurite de factori anatomo-fiziologici (trăsăturile mamei și fătului, resursele pe care le dețin și le procură cei 
doi, precum și chipul în care le gestionează), de creștere, de mediu, comportamental-interacționali, temperamentali etc.—care, la rîndul lor, își au proprii determinanți. Apoi, mișcările lichidului amniotic —un alt determinant parțial al amprentelor-se produc sub determinismul acțiunilor provocate de numeroși factori, în principal mișcările mamei și ale fătului-în relație cu caracteristicile fizice ale uterului, placentei, fătului, cu cantitatea și vîscozitatea lichidului amniotic etc. (Mulvihill \& Smith, 1969; Penrose \& Ohara, 1973; Okajima, 1975; Kimura \& Kitagawa, 1986; Okajima \& Yoshida, 1986; Babler, 1991; Kimura, 1991; Bentil \& Murray, 1993; Kücken \& Newell, 2004, 2005; Cummins, 2005; Raser \& O’Shea, 2005; Kücken, 2007; Patwari \& Lee, 2008; Wertheim, 2011).

Dincolo de joaca cu cuvintele. Deși imperfect și incapabil să reflecte realitatea, în măsura în care surprinde multiplele relații pe care le are gîndirea (cu realitatea, cu societatea, cu sine, cu limba), instrumentul lingvistic poate furniza informații nu doar asupra capacităților limbii, ci și asupra a ceea ce se petrece în gîndire. De aceea ar putea fi utilă observarea termenilor folosiți în discursul antiteleologizant și a conceptelor pe care încearcă aceștia a le purta.

Deși nimic nu este lipsit de cauze și nimic nu se petrece întîmplător-chiar dacă multe îi pot fi străine omului-, există mai mulți termeni care încearcă să redea o concepție contrară.

Din punct de vedere etimologic, termeni precum aleatoriu și hazard sînt echivalenți întrucît se referă la parcursul și la rezultatul imprevizibil al aruncării zarului. Desigur, dinainte ca zarul să fie aruncat, în timpul rostogolirii sau al zborului, sau chiar cu o clipă înainte de a încremeni, nimeni nu poate ști care va fi fața sa superioară. Pe baza unor calcule specifice teoriei probabilității se poate face o previziune avînd gradul de precizie aferent respectivei teorii, aplicate la o astfel de activitate. Cu toate acestea-după cum s-a văzut-, deși este imprevizibil, rezultatul final nu este pur întîmplător, el fiind determinat de acțiunea interferentă, conjugată și determinată a numeroși factori.

Toate acestea arată că sensurile ulterioare pentru aleator și hazard sînt dezvoltate ca urmare a unor judecăți sumare și simplificatoare, lipsite de temeiurile date de înțelegerea nuanțată și complexă a proceselor realității. Semnificația astfel încercată este 'pur accidental', 'absolut întîmplător', 'lipsit de orice determinism'. Acest fapt, însă, deja arată că dorința de a găsi un termen sau o sintagmă care să exprime un conținut de gîndire perfect antinomic cu cel exprimat de termenul determinat implică o dificultate care se convertește lesne în imposibilitate. Lucrurile stau astfel din simplul motiv că gîndirea poate născoci un astfel de construct, dar fără a obține corespondentul sau măcar un sprijin adiacent dinspre realitate, îi este greu să transforme-prin cuvînt-nebuloasa în formă lămurită.

Termenul des întrebuințat în literatura de specialitate anglo-americană și preluat la nivel internațional, random, poate funcționa ca o pură convenție, deși trimite la 'în viteză,' 'pe fugă,' 'în grabă', adică 'în neorînduială, ceea ce este mult prea puțin față de 'lipsit de orice fel și măsură de determinism'.

Unui termen precum gratuitate nu i se poate admite o accepțiune precum 'independența chimică dintre funcție și natura semnalelor chimice care o controlează’ (Monod, 1972), întrucît el trimite la ceva datorat bunului plac uman, lipsit de justificarea rațiunii suficiente, apropiindu-se întrucittva de concepte precum 'destin' sau 'soartă, unul dictat de bunul plac al zeilor, cealălalt de o fatalitate premergătoare chiar acestora, și care îi depășește și include adesea—atît de neînțeles de om încît, adesea, mintea sau intuiția acestuia îl califică drept ... „aleator”.

Desigur, valoarea etimologică a unui cuvînt nu interzice feluritele sale dezvoltări semantice, iar lipsa unui termen potrivit nu semnifică automat imposibilitatea existențială a conceptului. Pe de altă parte, lipsa unui termen potrivit—mai ales după două mii de ani de exercițiu conceptual şi mai cu seamă în cazul în care numeroși cercetători se străduie cu maximă aplecare să demonstreze că lucrurile stau aşa cum arată ei, iar nu altminteri-, avertizează cu seriozitate asupra caracterului neclar și chiar forțat al conceptului. La rîndul său, acest caracter indică cel puțin imposibilitatea demonstrării existenței unui corespondent în realitate, deci conceptul ar putea fi doar o plăsmuire, un element al unui construct mental complex, dar la fel de nebulos și de obscur. 
La rîndul său, determinat se poate referi fie la faptul că starea sau dezvoltarea a ceva au fost definite, parametrii fiind cunoscuți, fie la faptul că existența, exercițiul funcțional, dezvoltarea și evoluția a cevalucru sau proces-sînt supuse determinismului cauzal, adică se află în consecința acțiunii unuia sau mai multor factori cauzali direcți sau indirecți, eventual întrețesuți într-una sau mai multe rețele. Ceva aleator, hazardat, gratuit sau chiar arbitrar poate fi supus întîmplării, accidentului, și poate fi imprevizibil, impredictibil, dar toate acestea nu înseamnă cu necesitate că ar fi lipsit de orice determinare. Oricît de imprevizibilă pentru ființa umană, întîmplarea nu exclude determinismul natural, ea desfășurîndu-se în limite care o determină și care pot fi supuse în diferite grade calculului probabilităţii. Fie că acel ceva este emergent, fie că este privit din perspectivă cuantică, el rămîne supus determinismului, astfel încît absolut orice din Universul cunoscut este determinat. De altfel, caracterul determinat—în oricare dintre sensurinu ține de capacitatea sau de posibilitatea minții umane de a cuprinde relațiile cauzale ale rețelei (ceea ce poate face adesea cu lanțurile mai degrabă simple), de a cuantifica ordinea, ponderile și ierarhiile factorilor implicați în eveniment și de a prevedea evenimentul ori parametrii săi.

Ca urmare a exercițiului frecvent și intens al mușchilor scheletali, în respectivele țesuturi se produc modificări ale metilării $\mathrm{ADN}$-ului, mai întîi în regiunile care potențează transcrierea, asociate cu modificări relevante în exprimarea genică. Cu toate că nu se poate determina cu limpezime o relație cauzală, ar fi hazardat să se considere că înțelegerea umană și instrumentele ei au ajuns la apogeu, în așa fel încît dacă o asemenea relație încă nu a fost descifrată să se considere că existența ei ar fi imposibilă (Lindholm et al., 2014).

Probabil că, aici, cuvîntul-cheie este imprevizibil. Desigur, ceva este astfel din punctul de vedere al computerului uman care este creierul, fapt valabil—în principiu—pentru toți oamenii.

Ca de fiecare dată în istoria științei omenești, felurite progrese de metodă și de instrument încep să furnizeze teoriei tot mai multe date verificabile, iar amplificarea și aprofundarea capacității de a cuantifica și prevedea evenimente complexe duce la rezultate tot mai rezonabile. Astfel, tot mai multe procese, precum mutațiile, sînt extrase din zona neputinței numite aleator (Orr, 2010; Neher \& Shraiman, 2011; Avelar et al., 2013; Kosheleva \& Desai, 2013), sau apar dovezi că, de pildă, la nivelul diferitelor regiuni necodificatoare și nerepetitive ale genomului uman, pînă și ratele mutațiilor variază pe principii deterministe, iar nu „aleator” (Smith et al., 2002).

Avînd în vedere că nimic nu există în afara determinării și că unele realități nu pot fi prevăzute cu precizie (în apariția, dezvoltarea și evoluția lor), dar se supun legilor probabilității, termenul care redă optim conjuncția care generează acest complex de atribute este stohastic. În funcție de nivelul la care se petrece, o astfel de realitate este diferențiată ca tip de acțiune și ca forță, astfel încît stohasticitatea se manifestă întrun fel la nivel subnuclear, într-altul la nivel molecular, într-altul la nivelul celular, de organ, de organism, populație, sistem solar etc.

Decurgînd din faptul că limitele de variabilitate—din acel loc, timp, sistem etc.—sînt teribil de largi, stohasticitatea exprimă o condiție în care posibilitatea de apariție a unui fenomen este foarte ridicată, în vreme ce previzibilitatea cadrelor și a condițiilor (cînd, cum, unde, cît, în ce conjuncturi etc.) în și sub care va apărea și se va manifesta acesta este extrem de scăzută. Prin urmare, termenul stohastic se referă la un proces sau la un produs, privite din pespectiva statistică a previzibilității condițiilor sale, nu a posibilității apariției sale. Era imposibil ca forme de viață să nu apară la nivel de Univers, dar erau imprevizibile locul, modalitatea, momentul, durata, condițiile și alte limite ale acestor apariții.

Omnia sine Deo. Obstinația susținătorilor poziției neodarwiniste și antiteleologizante indică, pe de o parte, teama de prezența lui Dumnezeu. O teamă mai mare decît cea cuprinsă în credința practicantului religios și decît cea înghesuită în prejudecata superstițiosului-poate la un loc. O teamă care, prin sine, vădește credința în Dumnezeu. Unul pe care manevre evazive mistico-puerile-de la eludarea numelui și 
folosirea metaforică a sa, la negarea ființei și modificarea atributelor ei-l-ar putea face să dispară, cel puțin din acest Univers mental. Un Dumnezeu care a suferit de singura soartă pe care o putea aştepta de la om: fie de unul singur, fie forțat de imaginația omenească, el a creat fundamentele și principiile existențiale, de dezvoltare și evoluție (ca un demiurg), s-a revelat (ca un creator care înnobilează creația), a fost luat părtaș fără voie (ca un girant cu de-a sila anexat) la atrocități fizice și mentale, apoi împovărat cu toate păcatele (ca un mistic țap ispăşitor), apoi judecat, condamnat și ucis (ca un impostor și un tîlhar, ori ca un Tată care nu putea fi înlocuit după ce era onorat, ci numai după ce era dezonorat). Toate acestea s-au petrecut și se reiau astfel întrucît capacitatea oamenilor, de a ignora și disprețui, de a nesocoti și schimonosi este pur și simplu incomensurabilă - altfel Dumnezeu nu ar fi fost izgonit de pe domeniul mundan, surghiunit în ceruri, în subconștient sau aiurea, demonizat, negat ca o fantasmă, declarat mort și apoi metaforizat.

Deci nu de Dumnezeu le este oamenilor teamă.

Nibil ad hominem pertinet. Deși prezența și ordinea divină în lucruri și procese pot fi terifiante pentru oameni, dată fiind reziliența lor, ele nu-i îngrozesc. Ceea ce-i îngrozește pe oameni este propria capacitate de a comite inimaginabilul, în numele a ceva imaginabil—adică lupta oamenilor este cu ceilalți oameni.

Din perspectiva discuției de față, toate culturile umane admit că există lucruri și procese ce scapă minții umane sau o depășesc, și cu toții admit că raţiunea divină o transcende pe cea umană. În unele culturi, însă, rațiunea divină este necoincidentă cu cea umană, fiind incomprehensibilă, imprevizibilă și independentă de aceasta, în vreme ce în altele, rațiunea umană poate fi conectată la cea divină și capabilă de a o înțelege pe aceea-desigur, în măsura și pe porțiunile îngăduite ființei umane.

În prima concepție, divinitatea-deistic și aproape ateic separată de umanitate-acționează în modalități și cu rosturi ininteligibile pentru om, care nu are altă opțiune decît de a acționa în conformitate cu felul în care și-a construit propria morală. Întrucît morala pe care și-a construit-o nu poate fi decît diferită de felul de a fi al divinității, omul poate doar spera ca, din întîmplare și noroc, gîndurile și acțiunile să fie cumva pe placul divinității sau măcar tolerabile, astfel încît să beneficieze de îndurarea discreționară a acesteia-fie și gratuită, chiar și nejustificată.

În cea de-a doua concepție, divinitatea se comportă teistic, fiind implicată în lume, trasînd căile destul de lămurit și adesea călăuzind ființa umană. Omul poate greși ca urmare a neștiinței, a neînțelegerii, a execuției eronate etc., dar mai ales are posibilitatea de a alege într-o cunoștință de situație proporțională cu calitatea și gradul de educație religios-morală deținute-care sînt de natură să înrîurească însăși voința ființei umane.

În prima concepție, imaginarea unei divinități imperceptibile și neînțelese se conjugă cu arogarea de către om a statutului de legiuitor al propriilor fapte, ceea ce permite şi duce la paroxism hazardul și gratuitatea divine, alături de aleatorul și liberul arbitru umane-fie și a unui om orbecăind spre a nimeri divinitatea. Faptul rupe orice relație reală dintre om și divinitate, însă în mod fatal acel om rămîne o vietate care, chiar și cînd sfidează divinitatea, o face în chipul supusului răzvrătit.

În cea de-a doua, imaginarea unei divinităţi atotprezente, în conjuncție cu asumarea codului moralreligios trasat de divinitate elimină hazardul și instituie norma, limitează liberul arbitru și evidențiază determinarea, ceea ce duce la integrarea vieții omului în planul divinității.

Prigoana romantică. După aproximativ cinci generații în care o minoritate caracterizată printr-un exclusivism intransigent a încercat repudierea absolută a concepției teleologice și a limbajului aferent, iar o majoritate terorizată de cuvinte învestite cu forță acuzatoare nu a făcut decît să se comporte mimetic și în cele din urmă să cedeze, doar o mînă de cercetători, cu marele ajutor al realitățiii, a reușit să respingă situația impusă de calculele omenești, dar negată de chipul în care există și devine realitatea naturală. După ce Romantismul—care, în chip romantic, s-a considerat singurul care merita să dețină simțul văzului și orbea totul, de la necesitate la legi fonetice-și-a arătat caracterul nefast și după ce efectele sale au început să dispară, știința s-a redresat, dezvăluindu-și intacte fibrele ei milenare, în care nici divinitatea nu se confundă cu determinismul și cu necesitatea, nici determinismul și necesitatea nu sînt gîndite antropocentric. 
Timp de mai mult de un secol, știința antideterministă şi antiteleologică și-a canalizat toate energiile spre a aneantiza un presupus dușman — pe care de fiecare dată, în anumite condiții și măsuri, îl afla integru calitativ. Între timp, ea a înțeles că—dacă ar fi posibilă—eliminarea pînă și a limbajului teleologic ar presupune pierderi (grave), care ar afecta semnificațiile cuvintelor și mesajele enunțurilor, ambele cu consecințe conceptuale de tot felul (Beckner, 1969).

Toate acestea arată că, indiferent dacă perspectiva conceptuală determinist-finalistă izvorăște din felul natural al ființei umane de a înțelege lumea, de a se raporta la ea și de a o reflecta în gîndire și prin limbă, sau este doar o achiziție de parcurs, o dată întrețesută în ființa umană, orice tentativă de a suprima această perspectivă poate genera distrugeri iremediabile care, de fapt, dețin capacitatea de a aneantiza ori modifica radical fința umană.

Determinism și finalism. O dată apărută cumva, materia se structurează în baza trăsăturilor și proprietăților ei, constituie entități care funcționează în mediu conform cu structura constituită și cu capacitățile ei interacționale, se dezvoltă—prin combinare și complexificare-în acord cu valențele structurale și cu capacitățile funcțional-interacționale, se adaptează și evoluează în relație cu mediul, totul pe baza fundamentelor de principiu. Gama de potențial structural-funcțional și interacțional cu care este dotată entitatea generează un mănunchi de posibilități, actualizabile ca urmare a exercițiului entității-petrecut în acord cu trăsăturile ei structural-funcționale și interacționale. Ca existență, nu mănunchiul de posibilități contează, ci doar ceea ce se actualizează_fapt petrecut pe baze determinate (Brooks, 1895; Koonin, 2009). În acest context, la fiecare etapă de parcurs pot apărea valențe și capacităţi (structurale, funcționale, de dezvoltare, adaptative și evolutive), apte și dispuse către interacțiuni, care pot induce modificări de stare și de proces, mai mult sau mai puțin cuantificabile, astfel încît determinismul poate cunoaște grade ce dau aparența nedeterminării. Acest joc se petrece la fiecare pas, astfel încît, în funcție de situație, unele determinări vor prevala în mod previzibil, iar altele vor rămîne imprevizibile, permițînd evoluției să se petreacă, în consecința acțiunii forțelor contextuale.

Desigur, este pe potriva minții umane fie să imagineze în chip mistic o suprarealitate avînd din sine complexitatea necesară creării a tot ceea ce există, fie să refuze ipoteza unei astfel de preexistențe și să imagineze existența a ceva simplu și în măsură să inițieze un proces generator, din aproape în aproape, al unei realități mai complexe decît mintea umană și care, pe măsura complexificării, capătă noi posibilități și noi grade de autonomie, însoțite de liber arbitru și indeterminare.

Cele de mai sus arată că tot ceea ce există decurge din ceva anterior și se supune unor factori determinanți, adică are antecedenți și cauze, care dețin antecedenți și cauze, indiferent de dificultatea de a analiza exhaustiv elementele lanțului cauzal (adică de a le cuantifica forțele, ierarhia și ponderile, de a le stabili gradele de conjuncție, interdeterminare și colaborare, de a le monitoriza, matematiza și algoritmiza componentele), nimic nefiind aleatoriu și lipsit de determinare. $\mathrm{O}$ astfel de dificultate sau de imposibilitate nu poate genera sau constitui motiv de a concluziona că astfel de procese complexe ar fi indeterminate și aleatorii, întrucît ele sînt riguros determinate de o multitudine de factori inextricabil întrețesuți.

Însuși Darwin, supus necesităților care însoțesc procesul cunoașterii științifice și care împovărează demonstrația științifică, se vede aproape la tot pasul forțat să caute și să evidențieze cauzele stărilor și proceselor pe care le expune și descrie. De fiecare dată, el manifestă o aleasă și delicată conștiință a faptului că, adesea, cauzele sînt insezizabile, complexe, inextricabile, necunoscute și posibil necognoscibile - ceea ce nu înseamnă că ele nu există sau că nu funcționează generîndu-și efectele. De aceea, cu precauția care îl caracterizează, el arată deseori felul în care vede și concepe relația dintre cauză și hazard, aleator, întîmplare, după cum se reflectă în următoarea secvență, cu care se deschide capitolul despre chiar legile variației: „Pînă acum am vorbit despre variații (...) ca și cînd ele s-ar datora hazardului. Fără îndoială că expresia aceasta este cu totul incorectă, dar 
ea dă la iveală pe deplin ignoranța noastră cu privire la cauza fiecărei variații în parte” (Darwin, 1957).

Chiar dacă multe pot fi dificil de surprins de calculele sau de anticipările umane, toate acestea arată că, într-o realitate înlănţuită cauzal, nimic din ceea ce este fizic nu scapă determinismului fizic. Gradat prin circumstanțializare și contextualizare, determinismul este singurul care însoțește înrîuritor orice entitate și orice proces; nimic nu ascultă de ceva inexistent, cum este „aleatorul”, și nici nu poate exista fără a depinde de ceva.

La rîndul său, Dumnezeu nu are valoare explicativă și nici nu se ocupă cu amănuntele, dar din „inutilitatea" lui nu rezultă că el n-ar exista. Iar aşa cum existența sau inexistența divinității nu pot fi determinate și stabilite prin demonstrație ştiințifică, în condițiile în care nu există nici imuabilitate, atît datul, cît și întîmplarea sînt doar aparente și relative. În cele din urmă, totul pare a se supune unui neștiut complex de ordini ierarhizate, aşa cum s-a întrezărit şi s-a enunţat încă de la începutul secolului XX: „În aversiunea noastră față de vechea teleologie, atît de eficient surghiunită din știință de către Darwin, ar trebui să nu uităm că lumea, cea anorganică nu mai puțin decît cea organică, este plină de ordine. Într-adevăr, ce este întreaga dezvoltare a unui organism dacă nu o strictă și minunată ordonare? Pornind de la germenul primordial, fiecare etapă și întreaga secvență de etape nu sînt în mod riguros ortogenetice? Dacă variațiile sînt deviații în direcțiile proceselor de dezvoltare, ce minune se petrece dacă în anumite direcții există mai puțină rezistență la variație decît în altele? Ce minune este dacă organismul este atît de echilibrat încît să permită atît variații monovalente, cît și polivalente? (...) Dacă un proiectant stabilește limitele variației pentru a ajunge la un final dat, direcția evenimentelor este teleologică, dar dacă organizarea și legile de dezvoltare exclud unele direcții de variație în favoarea altora, cu siguranță că în asta nu există nimic supranatural, nimic din ceea ce ar putea fi incompatibil cu selecția naturală. Selecția naturală poate apărea în orice etapă a variației ortogenetice, poate reține și apoi modifica în diferite direcții rezultatele asupra cărora se poate să nu fi avut nici un control prealabil” (Whitman, 1906).

Cu toate că, probabil, termeni precum scop sau finalitate au fost concepuți din perspectivă antropocentrică, spre a exprima atribute ale acțiunilor ființei umane, ulterior extrapolate la comportamentele aparente ale altor entități-chiar nevii-, o judecată golită de perspectiva antropologică (în care, de regulă, scopul poate determina inițierea și parcursul), $i$-ar putea folosi. Ca urmare a acțiunii în cadre determinate a unor factori determinați deveniți determinanți, conjuncția mereu ajustabilă dintre cauză și parcurs conduce cu necesitate către o finalitate. După cum observa Darwin cînd vorbea despre „purposes of life”, la nivelul materiei vii finalitatea este dăinuirea eficientă (adică între limite optime în ceea ce privește consumul de resurse și efectele astfel produse, în relaţie cu condițiile existențiale—de la capacitățile organismului la cele de mediu). Iar dăinuirea viului este atît de imperios ordonată în țesătura viului, încît organismele care dețin erori ce tulbură grav și subminează viețuirea normală se pot chiar autodistruge.

\section{Bibliografie}

Avelar, A. T., Perfeito, L., Gordo, I. \& Ferreira, M. G. (2013). Genome architecture is a selectable trait that can be maintained by antagonistic pleiotropy, în „Nature Communications”, 4, 2235, Crossref.

Babler, W.J. (1991). Embryologic Development of Epidermal Ridges and Their Configurations, în „Birth defects original article series", 27 (2), p. 95-112.

Beckner, M. (1969). Function and teleology, în „Journal of the History of Biology”, 2, p. 151-164, Crossref.

Bentil, D.E. \& Murray, J.D. (1993). On the mechanical theory for biological pattern formation, în „Physica D: Nonlinear Phenomena”, 63 (1-2), p. 161-190, Crossref.

Brooks, W.K. (1895). An Inherent Error in the View of Galton and Weismann on Variation, în „Science”, 1 (5), p. 121-126, Crossref.

Cummins, H.G. (2005). Epidermal-ridge configurations in developmental defects, with particular reference to the ontogenetic factors which condition ridge direction, în „American Journal of Anatomy”, 38 (1), p. 89-151, Crossref.

Darwin, Ch. (1875). The Descent of Man, and Selection in Relation to Sex, New York.

Darwin, Ch. (1957). Originea speciilor prin selecție naturală sau păstrarea raselor favorizate în lupta pentru existențăa, (trad. Fuhn, I.E), București. 
Kimura, S. \& Kitagawa, T. (1986). Embryological development of human palmar, plantar, and digital flexion creases, în „The Anatomical Records", 216 (2), p. 191-197, Crossref.

Kimura, S. (1991). Embryologic development of flexion creases, în „Birth defects original article series”, 27 (2), p. $113-129$.

Koonin, E. V. (2009). Darwinian evolution in the light of genomics, în „Nucleic Acids Research”, 37 (4), p. 1011-1034, Crossref.

Kosheleva, K. \& Desai, M. M. (2013). The Dynamics of Genetic Draft in Rapidly Adapting Populations, în „Genetics”, 195 (3), p. 1007-1025, Crossref.

Kücken, M. \& Newell, A.C. (2004). A model for fingerprint formation, în „EPL. A letters journal exploring the frontiers of physics", 68 (1), p. 141-146.

Kücken, M. \& Newell, A. C. (2005). Fingerprint formation, în „Journal of Theoretical Biology”, 235 (1), p. 71-83, Crossref.

Kücken M. (2007). Models for fingerprint pattern formation, în „Forensic Science International”, 171 (2-3), p. 85-96, Crossref.

Lindholm, M.E., Marabita, Fr., Gomez-Cabrero, D., Rundqvist, H., Ekström, T.J., Tegnér, J. \& Sundberg, C.J. (2014). An integrative analysis reveals coordinated reprogramming of the epigenome and the transcriptome in human skeletal muscle after training, în „Epigenetics”, 9 (12), p. 1557-1569, Crossref.

Mayr, E. (1974). Teleological and Teleonomic: A New Analysis, în Cohen, R.S. \& Wartofsky, M. W. (eds), Boston Studies in the Philosophy of Science, vol. XIV, p. 91-117.

Mayr, E. (1988). Toward a New Philosophy of Biology. Observations of an Evolutionist, Harvard, 1988.

Mayr, E. (1992). The Idea of Teleology, în „Journal of History of Ideas”, 53 (1), ian.-mart., p. 117-135, Crossref.

Monod, J. (1972). Chance and necessity: An essay on the natural philosophy of modern biology, (trad. Wainhouse, A.), New York.

Mulvihill, J.J. \& Smith, D. W. (1969). The genesis of dermatoglyphics, în ,The Journal of Pediatrics”, 75 (4), p. 579-589, Crossref.

Neher, R. A. \& Shraiman, B. I. (2011). Genetic Draft and Quasi-Neutrality in Large Facultatively Sexual Populations, în „Genetics", 188 (4), p. 975-996, Crossref.

Okajima, M. (1975). Development of Dermal Ridges in the Fetus, în „Journal of Medical Genetics”, 12 (3), p. 243-250, Crossref.

Okajima, M. \& Yoshida, T.H. (1986). Ingeritance of Dermatoglyphyc Configuration in the Rat, în „The Journal of Heredity”, 77 (3), p. 169-174, Crossref.

Orr, H.A. (2010). The population genetics of beneficial mutations, în „Philosophical Transactions of the Royal Society of London. Serties B: Biological sciences”, 365 (1544), p. 1195-1201, Crossref.

Patwari, P. \& Lee, R. T. (2008). Mechanical Control of Tissue Morphogenesis, în „Circulation Research”, 103 (3), p. 234-243, Crossref.

Penrose, L.S. \& Ohara, P.T. (1973). The Development of Epidermal Ridges, în „Journal of Medical Genetics”, 10 (3), p. 201-208, Crossref.

Pittendrigh, C. (1958). Adaptation, Natural Selection and Behavior, în Roe, A. \& Simpson, G. G. (eds), Behavior and Evolution, p. 390-415.

Raser, J.M. \& O'Shea, E.K. (2005). Noise in Gene Expression: Origins, Consequences, and Control, în „Science”, 309 (5743), p. 2010-2013, Crossref.

Smith, N.G.C., Webster, M.T. \& Ellegren, H. (2002). Deterministic Mutation Rate Variation in the Human Genome, în „Genome Research”, 12 (9), p. 1350-1356, Crossref.

Wertheim, K. (2011). Embriology, Physiology, and Morphology of Friction Ridge Skin, în Fingerprint Sourcebook, cap. 3, p. 1-26. Whitman, C. O. (1906). The problem of the Origin of Species, în „Proceedings of Congress of Arts and Science”, 5, p. 46. 